\title{
Factors Affecting the Stock Price Movement: A Case Study on Dhaka Stock Exchange
}

\author{
Md. Shariful Islam¹, Mohammad Abdus Salam² \& Md. Mahmud Hasan ${ }^{2}$ \\ ${ }^{1}$ Department of Marketing, Jahangirnagar University, Savar, Bangladesh \\ ${ }^{2}$ Department of Accounting, Dhaka Commerce College, Mirpur, Bangladesh \\ Correspondence: Md. Shariful Islam, Department of Marketing, Jahangirnagar University, Savar, Dhaka, 1342, \\ Bangladesh. Tel: 88-0167-015-2474. E-mail: sharifjumkt39@gmail.com
}

Received: August 7, 2015

Accepted: September 10, 2015

Online Published: September 18, 2015

doi:10.5539/ijbm.v10n10p253

URL: http://dx.doi.org/10.5539/ijbm.v10n10p253

\begin{abstract}
Stock market is the mirror of the economy of any country. The strength of the economy reflects in the stock market numeric value. After crisis and fall down in different times over years, Bangladesh Stock Market is going to settle in a slow speed. Investors are hoping a strong stock market and management beyond political influential and invincible hands. There may exist hundreds or thousands of causes and events to bring effect on stock price in the capital market of Bangladesh. The study has selected 17 variables which appear to be effective for the movement of stock price in Bangladesh capital market. From the 17 variables through SPSS dimension reduction (or factor analysis) the study got 5 core factors which affect the stock price. The obtained factors are: Industry Performance, Market Influences, Company Performances, Investor Decisions, and Financial Considerations. Also to see the effect of selected variable on stock price movement, one variable - EPS is tested with stock price to see the effect. The result came that EPS is highly correlated to stock price movement in the capital market. As we have got different factors can affect the stock price movement. But investor should protect himself from the bad result of these factors. For this, before and after analysis in stock market business, the investors should consider about three main things which are acknowledged fully with company information \& performance, risk management and continuous monitoring of stock performance.
\end{abstract}

Keywords: Dhaka stock exchange, fundamental factors, ideal price of stock, EPS, stock price, stock price movement

\section{Introduction}

Dhaka Stock Exchange (DSE) is not sufficiently developed to be viewed as it as a perfect securities exchange. The origin of DSE occurred over sixty four years back. The need of setting up a stock trade in the then East Pakistan was first felt by the legislature, in mid-1952, when previous Indian government restricted Calcutta Stock Exchange from executing in Pakistani shares and securities. In Bangladesh, the main impetus of money related segment was truly the business banks. Capital business sector had fewer parts to play. This was because of the way that the general individuals of Bangladesh are for the most part moderate and they have a blended discernment about the danger example in capital business sector, accordingly fewer speculations were made by them in the early years of DSE. Yet, in the mid 90's capital business began to apparatus up which made individuals intrigued about stock trade. As individuals began to pour their cash in the warmed business it made a major air pocket and clearly it needed to blast. After the burst of 1997, controllers made numerous moves to settle the business. Thus the business began to rigging up for the second time. This time the greater parts of speculators were new and youthful with little information about the essentials or danger of the business sector. They again began to contribute their cash, at times obtained cash to put resources into the capital business sector. Thus again the interest pushed the business sector to rise yet with a much speedier burst that the past one. The bores wretchedly neglected to recover the confidence of financial specialists, which is clear from the successive vacillation in the record at present. It is evident that the business is currently during the time spent remedy, which was long past due. Be that as it may, it is imperative at this moment to know whether there is still space for further amendment. In this setting, this paper means to help financial specialists and different partners to settle on educated choice by distinguishing the variables that really impact the stock price. 


\section{Literature Review}

It is gotten a handle on that different variables have developed as determinants of offer costs for diverse markets to be specific profit, held income, size, profit per offer, profit yield, influence, payout proportion, book esteem per offer, remote conversion scale, GDP, giving premium rate, examiner reports, accessibility of substitutes, Government arrangement, speculator assessments, claims, macroeconomic basics, administration, market liquidity and soundness, mergers and takeovers, and specialized impacts. Scientist explored two imperative zones of behavioral fund; speculators' mindfulness about capital business sector and the administrations rendered by the financier houses by utilizing an organized poll in view of a review between times of August 2010-September 2010 on 76 individual financial specialists. The outcomes uncover that speculators are cognizant these days and have uplifting state of mind towards capital business sector. The financial specialists are contributing after deliberately exploring all business sector related issues. There is a huge hole in the middle of expected and genuine administration of financier houses. Reasons like high commission rate, non-helpful state of mind of agents, high record support expense and so forth made such contrasts. In the wake of breaking down overview results, instruction and control of the financial specialists are observed to be huge variables for venture, inclination and thought of purchasing shares while no impact of age and sex are found. As indicated by discoveries of the study, financial specialists are recommended to be capable toward both capital business sector circumstance and be aware of financier house administrations. There are absences of studies concerning individual financial specialists' conduct in Bangladesh (Farzana et al., 2012).

The sole center of this very research was to outline the real determinants of stock cost if there should be an occurrence of the biggest securities exchange in Bangladesh named as Dhaka Stock Exchange (DSE). The specialists have utilized board information relating to five divisions of DSE-Food and Allied, Fuel and Power, Engineering, Pharmaceuticals and Chemicals, and Healthcare parts for the period 2006-2010 and utilized completely altered standard slightest squares strategy. According to the examination result variables like - profit, value income proportion and influence were huge determinant of offer costs for all the previously stated parts. Also, benefit did impact offer costs just on account of the Food and Allied, Engineering, and Healthcare parts separately (Elizabeth \& Haryati, 2012).

\section{Rationale of the Study}

The rationale of the report topic is that the volatility of stock price movement over few years is very high. Even capital market experienced with the lowest and highest stock exchange point in the meantime. There are different causes and events which affects the stock movement in Bangladesh capital market. But constituted composite of the cause and events, which factors affect the stock price most is important to find. Different researches have made related to this topic in different ways. But the study has selected its own variables which affects the stock price movement very high. For the above reasons, we have made decision to prepare a research on factors affecting the stock price movement in Bangladesh.

\subsection{Research Questions}

The specific research Questions are given below:

a) What factors affect stock price movement in Bangladesh capital market?

b) Whether EPS as a factor of variables can change the stock price?

c) How Stockholders thinks about factors that affect stock price movement?

\subsection{Objective of the Study}

We have carried out this study to find out some key issues about price movement factors of stock market in Bangladesh. As a result we have developed some objectives of this study.

\subsection{Core Objective}

The core objective of this study is to find out what factor or factors influence stock market price movement. It is also to find the answer of the research questions which have been given in the previous Para.

\subsection{Specific Objectives}

Some specific objectives of this study are:

- Determine the factors from selected variables which can affect the stock price movement in the capital market of Bangladesh.

- $\quad$ Find the opinion of different stockholders of different company's stock on factors that affect the stock price movement. 
- Test of EPS if EPS declaration can affect the stock price?

- To give some recommendations for the betterment of the stockholder in stock trading.

\section{Methodology}

This study is broadly designed to find out the influence factors of changing the stock price. Besides the paper endeavors to contrasts the business sector cost of shares and their optimal cost to figure out if these stocks are as of now exaggerated or underestimated.

\subsection{Research Design}

This study is done in an exploratory research design method. The objectives of the study are to find the factors. So, it is an exploratory research. But there will be recommendation based on results too.

\subsection{Data Sources}

There are two sources of data which have been used in the study: 1) primary sources and 2) secondary sources. Primary data is the first hand information or raw information which has collected at first time. In the study, the responses on variables which have collected from 30 respondents is source of primary data. Source of data which has collected from different articles, research, report, thesis paper or from websites is called secondary data. In this study, several research papers have been viewed from the determination research design and formula. Also data have collected from different websites for the DSE and other websites.

\subsection{Sampling Plan and Data Collection Procedures}

This study is narrow, so sample size of respondents is only 30 . After determining the sample size the data were collected from selected stakeholder of capital market who was convenient to us. Data were collected through a formal questionnaire. Questionnaire was divided into two parts - personal information and variables list. Respondents were asked to put mark on the variables by determining how the variable affects the stock price movement. In this study, Likert scaling technique has been used to code data. In this likert scaling technique, 5 response categories have been used ranging from 1(minimum) to 5 (maximum). The label of these 5 response categories are like $1=$ strongly agree, $2=$ agree, $3=$ Neutral, $4=$ disagree and $5=$ strongly disagree.

\subsection{Data Analyzing Techniques}

Statistical method of factor analysis has been applied in this study. Analysis of data is required to fulfill the objectives of report, to find out the factors and to bring correlation between one variable (EPS) and stock price movement.

\section{Analysis of the Study}

Among 17 variables, to determine the factors all variables are rotated into SPSS statistics application. The results are given below to show obtained factors and related information.

\section{Output-1: Descriptive Statistics}

In the table below, the noticeable values are - first question have got mean value 4.70 which means respondents agree strongly that EPS is a considerable factor in dictating the stock price movement. Also the standard deviation of the variable is .47 and covariance $10 \%$ which indicates very less difference in opinions of the respondents.

In the below part, the variable (trends play powerful part at monitoring stock price movement) has got mean value 4.90 and standard deviation .31 which indicates respondents are strongly agree with that variable which can change stock price. The values are showing strongest among the total 17 variables. 
Table 1. Descriptive statistics

\begin{tabular}{llll}
\hline & Mean & SD & N \\
\hline Can EPS be a considerable factor in dictating the stock price movement & 4.70 & .47 & 30 \\
To what extent do you find P/E ratio influencing stock price movement & 4.00 & .83 & 30 \\
Do you think dividend can be important to stock price movement & 3.00 & 1.23 & 30 \\
Stock splits are important to the maintenance of stock price movement & 3.20 & 1.10 & 30 \\
Do you find Share Buy Back important & 2.57 & 1.10 & 30 \\
Company news can be factorial to the stock price movement & 2.93 & 1.08 & 30 \\
Industry performance can be crucial & 4.33 & .71 & 30 \\
Investors' sentiment is an important dimension to consider & 3.07 & 1.08 & 30 \\
Do you think economic factors are important & 4.63 & .49 & 30 \\
Do you think Takeover or Merger affect stock price & 3.03 & 1.42 & 30 \\
Do you think new product introduction and practicing are important & 3.77 & 1.04 & 30 \\
Insider trading can affect stock price movement & 3.83 & .98 & 30 \\
Economic strength of market or peer should be considered as affecting & 4.50 & .51 & 30 \\
Substitutes are influencers at dictating stock pricing & 4.33 & .71 & 30 \\
Incidental transactions are also viable to be taken as affecters & 2.53 & 1.27 & 30 \\
Trends play powerful part at monitoring stock price movement & 4.90 & .31 & 30 \\
Liquidity plays important role at setting and maintaining stock price movement & 3.87 & .86 & 30 \\
\hline
\end{tabular}

Among others variables Economic strength of market has means value 4.50 (standard deviation .51); Industry performance (mean 4.33 and sd .71); Economic Factors (mean 4.63 and SD .49); Substitutes (mean 4.33 and SD .71) - all are showing strong values which indicates respondents are strongly agree in these variables that these variables can change the stock price movement in Bangladesh.

In the meantime, we also see that variables like-Do you find Share Buy Back important (mean 2.57 and SD 1.10); Company news can be factorial to the stock price movement (mean 2.93 and SD 1.08); and Incidental transactions are also viable to be taken as affecters (mean 2.53 and Standard deviation 1.27) - have got lowest mean value with highest standard deviation value and also the covariance value for these three variables are $42.8 \%, 36.86 \%$ and $50.20 \%$ respectively.

\section{Output-2: KMO and BARTLETT's Test}

Kaiser-Meyer-Olkin (KMO) measure of Sampling Adequacy, if the value is greater than .5 that indicates factor analysis might be applied to these data.

Moreover, Bartlett's measure tests the null hypothesis that the original correlations matrix is an identity matrix. For factor analysis to work we need some relationship between variables and if the R-matrix were and identity matrix then all correlations would be zero. Therefore we need this test to be significant (or have a significance value less than 0.05). A significant test tells us that the R-matrix is not an identity matrix; there are some relationships between the variables we hope to include in the analysis.

Table 2. KMO and Bartlett's test

\begin{tabular}{lll}
\hline Kaiser-Meyer-Olkin Measure of Sampling Adequacy. & .535 \\
\hline Bartlett's Test of Sphericity & Approx. Chi-Square & 240.352 \\
& df & 136 \\
& Sig. & .000 \\
\hline
\end{tabular}

From our SPSS output on KMO and Bartlett's Test it is seen that the Kaiser-Meyer-Olkin Measure of Sampling Adequacy value is 0.535 which means the sampling adequacy is acceptable but not good.

\section{Output-3: Factor Extraction}

The eigenvalues associated with each factor represent the variance explained by that particular linear component and SPSS also displays the eigenvalue in terms of the percentage of variance explained. The Component (factor) 1 explains $24.322 \%$ of total variance. It should be clear that the first few factors explain relatively large amounts of variance (especially factor 1,2,3) whereas subsequent factors explain only small amounts of variance. SPSS then extracts all factors with eigenvalues greater than 1 , which leaves us with four factors. The eigenvalues 
associated with these factors are displayed with the percentage of variance explained in the columns labelled Extraction Sums of Squared Loadings. The values in this part of the table are the same as the values before extraction, except that the values for the discarded factors are ignored.

Table 3. Total variance explained

\begin{tabular}{|c|c|c|c|c|c|c|}
\hline \multirow[t]{2}{*}{ Component } & \multicolumn{3}{|c|}{ Initial Eigenvalues } & \multicolumn{3}{|c|}{ Extraction Sums of Squared Loadings } \\
\hline & Total & $\%$ of Variance & Cumulative \% & Total & $\%$ of Variance & Cumulative $\%$ \\
\hline 1 & 4.135 & 24.322 & 24.322 & 4.135 & 24.322 & 24.322 \\
\hline 2 & 2.794 & 16.438 & 40.760 & 2.794 & 16.438 & 40.760 \\
\hline 3 & 2.496 & 14.683 & 55.443 & 2.496 & 14.683 & 55.443 \\
\hline 4 & 1.494 & 8.786 & 64.229 & 1.494 & 8.786 & 64.229 \\
\hline 5 & 1.377 & 8.102 & 72.331 & 1.377 & 8.102 & 72.331 \\
\hline 6 & .951 & 5.592 & 77.923 & & & \\
\hline 7 & .828 & 4.872 & 82.795 & & & \\
\hline 8 & .718 & 4.222 & 87.017 & & & \\
\hline 9 & .446 & 2.626 & 89.643 & & & \\
\hline 10 & .404 & 2.374 & 92.017 & & & \\
\hline 11 & .380 & 2.235 & 94.252 & & & \\
\hline 12 & .272 & 1.600 & 95.851 & & & \\
\hline 13 & .185 & 1.091 & 96.942 & & & \\
\hline 14 & .181 & 1.063 & 98.005 & & & \\
\hline 15 & .158 & .929 & 98.934 & & & \\
\hline 16 & .126 & .742 & 99.676 & & & \\
\hline 17 & .055 & .324 & 100.00 & & & \\
\hline
\end{tabular}

Table 4. Total variance explained

\begin{tabular}{lllllll}
\hline \multirow{2}{*}{ Component } & \multicolumn{2}{l}{ Extraction Sums of Squared Loadings } & \multicolumn{3}{l}{ Rotation Sums of Squared Loadings } \\
\cline { 2 - 7 } & Total & \% of Variance & Cumulative \% & Total & \% of Variance & Cumulative \% \\
\hline 1 & 4.135 & 24.322 & 24.322 & 3.033 & 17.841 & 17.841 \\
2 & 2.794 & 16.438 & 40.760 & 2.548 & 14.988 & 32.830 \\
3 & 2.496 & 14.683 & 55.443 & 2.548 & 14.988 & 47.818 \\
4 & 1.494 & 8.786 & 64.229 & 2.377 & 13.980 & 61.798 \\
5 & 1.377 & 8.102 & 72.331 & 1.791 & 10.533 & 72.331 \\
\hline
\end{tabular}

Before rotation, factor 1 account for considerably more variance than the remaining three $(24.322 \%$ compared to $16.438 \%, 14.683 \%, 8.786 \%, 8.102 \%)$, however after extracting it accounts for only $17.841 \%$ of variance (compared to $14.988 \%, 14.988 \%, 13.980 \%, 10.533 \%$ respectively).

\section{Output-4: Communalities and Component Matrix}

Before extraction the communalities are all 1 . The communalities in the column labelled extraction reflect the common variance in the data structure. The amount of variance in each variable that can be explained by the retained factors is represented by the communities after extraction. So, for example $43.5 \%$ of the variance associated with question 1 is common, or shared, variance. 
Table 5. Communalities

\begin{tabular}{lll}
\hline & Initial & Extraction \\
\hline Can EPS be a considerable factor in dictating the stock price movement & 1.000 & .435 \\
To what extent do you find P/E ratio influencing stock price movement & 1.000 & .600 \\
Do you think dividend can be important to stock price movement & 1.000 & .733 \\
Stock splits are important to the maintenance of stock price movement & 1.000 & .539 \\
Do you find Share Buy Back important & 1.000 & .651 \\
Company news can be factorial to the stock price movement & 1.000 & .747 \\
Industry performance can be crucial & 1.000 & .744 \\
Investors' sentiment is an important dimension to consider & 1.000 & .743 \\
Do you think economic factors are important & 1.000 & .731 \\
Do you think Takeover or Merger affect stock price & 1.000 & .798 \\
Do you think new product introduction and practicing are important & 1.000 & .820 \\
Insider trading can affect stock price movement & 1.000 & .813 \\
Economic strength of market or peer should be considered as affecting & 1.000 & .848 \\
Substitutes are influencers at dictating stock pricing & 1.000 & .805 \\
Incidental transactions are also viable to be taken as a factor & 1.000 & .761 \\
Trends play powerful part at monitoring stock price movement & 1.000 & .754 \\
Liquidity plays important role at setting and maintaining stock price & 1.000 & .774 \\
\hline
\end{tabular}

By Kaiser's criterion we have got five factors. However, this criterion is accurate when there are less than 30 variables and communalities after extraction are greater than 0.7 From commonalties table, we can see that the total number of variables are 17 (lower than 30) and the average value after extraction is 0.723 (higher than required 0.7). So, it is acceptable to retain all factors with eigenvalues above 1 (Kaiser's criterion).

\section{Output-5: Scree Plot}

The scree plot shows the eigenvalue into graph. In the scree plot, it is seen that 5 factors has got 1 eigenvalues and they are above the value 1 . Other variables are under 1 and goes down to end to number 17.

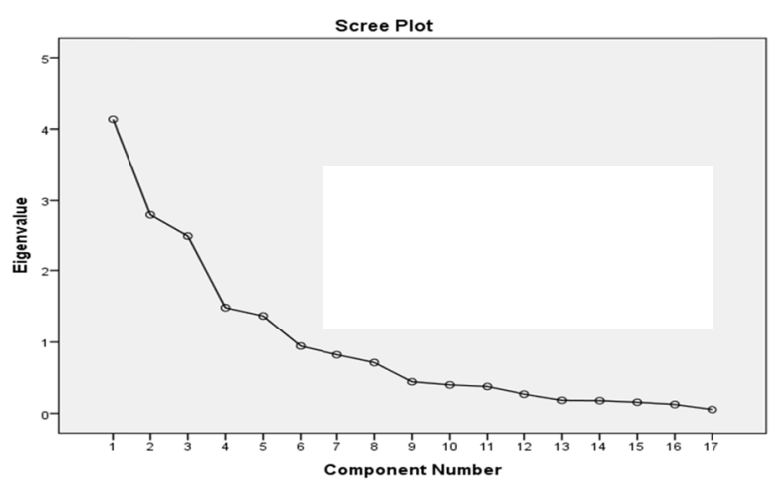

Figure 1. Scree plot

\section{Output-6: Rotated Component Matrix}

The rotation of the factors structure has clarified things considerably: there are five factors and variables load very highly loaded in different factors. The suppression of loadings less than 0.4 and ordering variables by loading size also makes interpretation considerably easier. 
Table 6. Rotated component matrix

\begin{tabular}{|c|c|c|c|c|c|}
\hline & \multicolumn{5}{|c|}{ Component } \\
\hline & 1 & 2 & 3 & 4 & 5 \\
\hline Incidental transactions & -.834 & & & & \\
\hline Substitutes are influencers & .796 & & & & \\
\hline Economic factors & -.749 & & & & \\
\hline Industry performance & .612 & & .606 & & \\
\hline Dividend & .576 & & & -.467 & \\
\hline Economic strength of market or peer & & .848 & & & \\
\hline Do you think Takeover or Merger affect stock price & & .837 & & & \\
\hline Insider trading can affect stock price movement & & .746 & .436 & & \\
\hline New product introduction and practicing & & & .839 & & \\
\hline Liquidity at setting and maintaining stock price & & & -.718 & & \\
\hline Company news & & & -.652 & .458 & \\
\hline $\mathrm{P} / \mathrm{E}$ ratio & & & & .763 & \\
\hline Share Buy Back & & & & .702 & \\
\hline Investors' sentiment & & & .441 & -.624 & \\
\hline Stock splits & & & & & .728 \\
\hline Trends & & & & & .727 \\
\hline EPS & & & & & -.416 \\
\hline
\end{tabular}

Table 7. Factors labelling

\begin{tabular}{|c|c|c|c|}
\hline Factors & Loaded Variables & $\begin{array}{l}\text { Factor } \\
\text { Loadings }\end{array}$ & Comment \\
\hline \multirow{6}{*}{$\begin{array}{l}\text { Factor }-1 \text { : } \\
\text { Industry } \\
\text { Performance }\end{array}$} & Incidental transactions & -.834 & \multirow{5}{*}{$\begin{array}{l}\text { By considering loaded variables of the factor, it could be named as industry } \\
\text { performances. As all variables are related to the performance of industry } \\
\text { performance like substitute influences, industry performance, economics } \\
\text { performances etc. }\end{array}$} \\
\hline & $\begin{array}{l}\text { Substitutes } \quad \text { are } \\
\text { influencers }\end{array}$ & .796 & \\
\hline & $\begin{array}{l}\text { Influencers } \\
\text { Economic factors }\end{array}$ & -.749 & \\
\hline & Industry performance & .612 & \\
\hline & Dividend & .576 & \\
\hline & $\begin{array}{l}\text { Economic strength of } \\
\text { market or peer }\end{array}$ & .848 & \multirow{4}{*}{$\begin{array}{l}\text { By considering loaded variables under the factor } 2 \text { it should be named as } \\
\text { market performances. Economic strength of market or peer, Takeover or } \\
\text { merger trend affect and insider trading is under the market factors. }\end{array}$} \\
\hline \multirow{3}{*}{$\begin{array}{l}\text { Factor }-2 \text { : } \\
\text { Market } \\
\text { Performances }\end{array}$} & Do you think & .837 & \\
\hline & $\begin{array}{l}\text { Takeover or Merger } \\
\text { affect stock price }\end{array}$ & & \\
\hline & $\begin{array}{l}\text { Insider trading can } \\
\text { affect stock price } \\
\text { movement }\end{array}$ & .746 & \\
\hline \multirow{5}{*}{$\begin{array}{l}\text { Factor }-3 \text { : } \\
\text { Company } \\
\text { Performances }\end{array}$} & $\begin{array}{lr}\text { New } & \text { product } \\
\text { introduction } & \text { and } \\
\text { practicing } & \end{array}$ & .839 & \multirow[t]{4}{*}{$\begin{array}{l}\text { By considering loaded variables under the factor } 3 \text { it should be named as } \\
\text { company performances. Because company news, new product introduction } \\
\text { and liquidity fall under the performance of company in the market. }\end{array}$} \\
\hline & Liquidity at setting & -.718 & \\
\hline & $\begin{array}{l}\text { and maintaining stock } \\
\text { price }\end{array}$ & & \\
\hline & Company news & -.652 & \\
\hline & $\mathrm{P} /$ E ratio & .763 & \multirow{3}{*}{$\begin{array}{l}\text { By considering loaded variables under the factor } 3 \text { it should be named as } \\
\text { investor decisions. Because depending on } \mathrm{P} / \mathrm{E} \text { ratio investor decides what to } \\
\text { do, share buyback depends on investor opinion and investor's sentiment } \\
\text { already related to Investors Decisions. }\end{array}$} \\
\hline Factor - 4: & Share Buy Back & .702 & \\
\hline $\begin{array}{l}\text { Investor } \\
\text { Decisions }\end{array}$ & Investors' sentiment & -.624 & \\
\hline Factor - 5: & Stock splits & .728 & \multirow{3}{*}{$\begin{array}{l}\text { By considering loaded variables under the factor } 3 \text { it should be named as } \\
\text { financial considerations. Because trends related to financial performance of } \\
\text { the total industry, other two is indirectly related to Financial Considerations. }\end{array}$} \\
\hline Financial & Trends & .727 & \\
\hline Considerations & EPS & -.416 & \\
\hline
\end{tabular}


After factor analysis of variables it is clear that from the result that the stock price movement in Bangladesh capital market depends on five factors. The factors are: (1) Industry Performance, (2) Market Influences, (3) Company Performances, (4) Investor Decisions, and (5) Financial Considerations.

\subsection{Relationships between EPS and Stock Price Movement}

Here, it has been shown an empirical study that shows the relationship between shares price and earnings per share that means profitability. It has been shown two things that are share price before declaring dividend and after declaring dividend. To do this, we have taken DSE-05 shares as sample data. Total process is as following:-

1) Sample data is DSE-05 shares.

2) Moving average to calculate the average price and average EPS.

3) Converted some par value into Tk. 10 for convenience.

4) First, it has shown how strongly share price is related to without EPS.

5) Secondly, it has shown how strongly share price is related to with EPS.

6) Then we have analysis this relationship by coefficient of correlation [r] and coefficient of determination [r2].

Table 8. Sample data of EPS

\begin{tabular}{llll}
\cline { 2 - 4 } Company & Before EPS Price (X) & After EPS Price (Y) & EPS AVERAGE \\
\cline { 2 - 4 } Islami Bank Bd Ltd & 61.9 & 64.04 & 4.75 \\
NBL & 82.5 & 73.15 & 15.57 \\
Prime Bank & 53.8 & 69.78 & 5.96 \\
Southeast Bank & 37.93 & 48.7 & 5.42 \\
Dhaka Bank & 55.5 & 48.67 & 6.31 \\
\hline
\end{tabular}

Source: DSE monthly review.

Before EPS Price: These prices are taken 3 months later after giving dividend by the moving average.

After EPS Price: These prices are taken after declaring dividend by the motioned company over the year using moving average (Cash, Bonus Share or Right Share Issue).

Table 9. $\mathrm{R} \& \mathrm{R}^{2}$ calculation

\begin{tabular}{lll}
\hline Company & Before EPS Price (X) & After EPS Price (Y) \\
\hline Islami Bank Bd Ltd & 61.9 & 64.04 \\
NBL & 82.5 & 73.15 \\
Prime Bank & 53.8 & 69.78 \\
Southeast Bank & 37.93 & 48.7 \\
Dhaka Bank & 55.5 & 48.67 \\
\hline
\end{tabular}

Note. Correlation coefficient R: 0.980445635 and Coefficient of determination. $R^{2}: 0.961273643$ (From SPSS sheet).

\subsection{Interpretation and Findings}

Interpretation $\mathbf{R}^{2}: \mathrm{R}^{2}$ is a measurement that will give some data about the integrity of attack of a model. In relapse, the $\mathrm{R}^{2}$ coefficient of determination is a factual measure of how well the relapse line approximates the genuine information focuses. $\mathrm{A} \mathrm{R}^{2}$ of 1.0 shows that the relapse line consummately fits the information. Estimations of $\mathrm{R}^{2}$ outside the extent 0 to 1 can happen where it is utilized to gauge the understanding in the middle of watched and demonstrated qualities and where the "displayed" qualities are not acquired by direct relapse and relying upon which definition of $\mathrm{R}^{2}$ is utilized. In the event that the first equation above is utilized, qualities can never be more prominent than one. In the event that the second expression is utilized, there are no requirements on the qualities reachable. In our study the outcome is 0.961273643 . So it communicates two variables impeccably.

Interpretation R: The connection coefficient is a number somewhere around 0 and 1 . In the event that there is no relationship between the anticipated qualities and the genuine qualities the connection coefficient is 0 or low (the anticipated qualities are no superior to anything arbitrary numbers). The quality of the relationship between the anticipated qualities and real values builds so does the connection coefficient. An impeccable fit gives a coefficient 
of 1.0. Consequently the higher the relationship coefficient the better it is. Here, our result is $\mathbf{0 . 9 8 0 4 4 5 6 3 5}$, which is near about 1 . Therefore, EPS and share price is highly correlated. Indeed, we can say when one company declared dividend then the price increases.

Appropriateness of factor analysis is measured through Kaiser-Meyer-Olkin test and the result shows that factor analysis is the ideal method of analyzing the data. Initial eigenvalue indicates the control of individual component. Among 17 components, 5 components are retained on the basis of eigenvalue. These five components have total $72.331 \%$ of variance. As a result it can be summarized that these five components have $72.331 \%$ influential power to move the price of stock market. The total eighteen variables are extracted into five factors and these five factors are labeled as follows: Industry Performance, Market's Performance, Company Performance, Investor Decisions, and Financial Considerations. Finally it can be said these five factors affect the price movement of stock market.

\subsection{Recommendation}

As we have got different factors can affect the stock price movement. But investor should protect himself from the bad result of these factors. For this, before and after in stock market business the investors should follow the common regulations which are given below:

$>$ Know the company what the investors are going to invest by being acknowledged with;

- Financial performance of the company; Company's track record;

- Business Cost; Risk Factors; Dividend History;

- Leadership;

$>$ To reduce the risk in stock business the investor's should consider these recommendation;

- Holding of diversified stock portfolio;

- Invest for the long term;

- Don't try to time the market, after a sudden time price can fall so fast;

- Get advice if the investor is not a knowledgeable investor;

- Be careful about buying private stock;

- Be aware of the dangers of investing offshore;

$>$ Continuous monitoring of stock performance;

- Review your account statements;

- Check stock tables;

- Compare against benchmarks;

- Get current news on the companies you're invested in;

- Use indicators to re-asses investment decisions;

- Consult with advisor;

- Follow stock market news;

- Keep up with general economic news;

As we know that the investors can get information on a company, investor can check different disclosure documents, annual reports, news release, and company websites.

\section{Conclusion}

There may exist hundreds or thousands of causes and events to bring effect on stock price. The study has selected 17 variables which appear to be effective for the movement of stock price. From the 17 variables through SPSS dimension reduction (or factor analysis) the study got 5 core factors which affect the stock price. The obtained factors are: Industry Performance, Market Influences, Company Performance, Investor Decisions, and Financial Considerations. Also to see the effect of selected variable on stock price movement, one variable EPS is tested with stock price to see the effect. The result came that EPS is highly correlated to stock price movement in the capital market.

\section{References}

Elizabeth, C. K., \& Haryati, S. (2012). Determinants of Stock Prices in Dhaka Stock Exchange (DSE), 
Bangladesh. European Journal of Developing Country Studies, 13. Retrieved from http://docslide.us/documents/determinants-of-stock-prices-in-dhaka-stock-exchange-dse-55844d92f24ff.ht $\mathrm{ml}$

Farzana, W., Rahman, M. I., \& Mazumder, M. N. H. (2012). Behavioral Financing: Demographic Factors and Services of Brokerage Houses in Bangladesh. World Journal of Social Sciences, 2(4), 15-33.

Nasif AL-Shubiri, F. (2010). Analysis the Determinants of Market Stock Price Movements: An Empirical Study of Jordanian Commercial Banks. International Journal of Business and Management, 5(10). http://dx.doi.org/10.553/ijbm.v5n10p137

\section{Copyrights}

Copyright for this article is retained by the author(s), with first publication rights granted to the journal.

This is an open-access article distributed under the terms and conditions of the Creative Commons Attribution license (http://creativecommons.org/licenses/by/3.0/). 